\title{
ANALISIS RASIO PROFITABILITAS PADA PT. SILOAM HOSPITALS INTERNATIONAL, TBK.
}

\author{
Teti Anggit Safitri \\ Program Studi Manajemen, Universitas 'Aisyiyah Yogyakarta \\ E-mai:tetianggita@unisayogya.ac.id
}

\begin{abstract}
ABSTRAK
Penelitian ini bertujuan untuk mengetahui kinerja keuangan perusahaan dengan menggunakan analisis rasio profitabilitas, di mana rasio profitabilitas merupakan rasio yang bertujuan untuk mengetahui kemampuan perusahaan dalam menghasilkan laba selama periode tertentu dan juga memberikan gambaran tentang tingkat efektivitas manajemen dalam melaksanakan kegiatan operasinya. Rasio profitabilitas terdiri dari tiga rasio antara lain Return On Asset, Return On Equity, dan Net Profit Margin. Objek penelitian yaitu PT Siloam Hospitals International Tbk, di mana perusahaan jasa kesehatan tersebut telah melakukan IPO (Initial Public Offering) atau penawaran umum perdana sehingga pertumbuhan ekonomi perusahaan sangat pesat. Tujuan penelitian ini adalah untuk menguji adalah untuk menganalisis kinerja keuangan perusahaan pada PT. Siloam Hospitals International Tbk tahun 2014 - 2017 jika ditinjau dari rasio profitabilitas. Sampel penelitian ini yaitu PT Siloam Hospitals International Tbk tahun $2014-2017$
\end{abstract}

Kata Kunci:Rasio Profitabilitas, Initial Public Offering

\begin{abstract}
This study aims to determine the company's financial performance by using profitability ratio analysis, where the profitability ratio is a ratio that aims to determine the company's ability in generating profit over a certain period and also provides an overview of the level of management effectiveness in carrying out its operations. Profitability ratio consists of three ratios, among others Return On Assets, Return On Equity and Net Profit Margin. The research object is PT Siloam Hospitals International Tbk, where the health services company has done IPO (Initial Public Offering) or initial public offering so that economic growth of company very rapidly. The purpose of this study is to test is to analyze the financial performance of the company at PT. Siloam Hospitals International Tbk. year 2014 - 2017 if reviewed from the profitability ratio. The sample of this research is PT Siloam Hospitals International Tbk year 2014 - 2017
\end{abstract}

Keywords : Profitability Ratios, Initial Public Offering 


\section{PENDAHULUAN}

Pertumbuhan industri kesehatan di Indonesia semakin berkembang pesat di mana masyarakat semakin peduli dengan kesehatannya, berbagai rumah sakit mulai berlomba-lomba memberikan pelayanan yang terbaik bagi pasiennya, salah satunya PT Siloam Hospitals International Tbk. Perusahaan ini mengoperasikan jaringan rumah sakit swasta terbesar di Indonesia. Initial Public Offering (IPO) dikenal sebagai gerbang bagi perusahaan memperoleh dana investor sebanyak-banyaknya dari investor untuk menambah permodalan bisnisnya sehingga dengan banyaknya investor yang ikut serta memberikan bantuan permodalan, perusahaan dapat melebarkan sayap bisnis PT Siloam Hospitals International Tbk.

PT Siloam International Hospitals Tbk (SILO) didirikan tanggal 3 Agustus 1996 dengan nama PT Sentralindo Wirasta. Ruang lingkup kegiatan SILO adalah dalam bidang pelayanan kesehatan masyarakat, termasuk mendirikan dan mengelola rumah sakit, poliklinik, sarana dan pra sarana penunjang kesehatan, menyelenggarakan pelayanan dan penyelenggaraan kesehatan serta menyelenggarakan jaminan pemeliharaan kesehatan masyarakat. Kegiatan utama SILO yaitu bergerak dalam bidang pelayanan kesehatan masyarakat dengan mendirikan dan mengelola rumah sakit yang telah memiliki kapasitas 4.800 tempat tidur dengan 1.700 dokter spesialis dan 2.100 dokter serta 8.200 perawat, rekanan teknisi kesehatan, dan staf pendukung.Pada tanggal2 September 2013, SILO memperoleh pernyataan efektif dari Otoritas Jasa Keuangan (OJK) untuk melakukan Penawaran Umum Perdana Saham SILO (IPO) kepada masyarakat sebanyak 156.100.000 dengan harga penawaran Rp9.000,- per saham. Sahamsaham tersebut dicatatkan pada Bursa Efek Indonesia (BEI) pada tanggal 12 September 2013.Memulai bisnis pada tahun 1996 dengan nama awal PT Sentralindo Wirasta dan berkembang menjadi 4 rumah sakit di tahun 2010, saat ini perseroan mengelola dan mengoperasikan 23 rumah sakit di seluruh Indonesia, yang terdiri dari 8 rumah sakit di kawasan Jabodetabek dan 15 rumah sakit yang tersebar di Jawa, Sumatera, Kalimantan, Sulawesi, Bali dan Nusa Tenggara. Dari 23 rumah sakit yang beroperasi, 16 rumah sakit sudah melayani pasien BPJS.

Pertumbuhan jumlah rumah sakit dalam naungan PT Siloam Hospitals International Tbk yang cukup besar tersebut menumbuhkan ketertarikan bagi peneliti untuk membahas bagaimana pertumbuhan kinerja keuangannya dilihat dari rasio profitabilitasnya, karena rasio profitabilitas mewakili kesuksesan perusahaan dan bagaimana kontribusinya bagi kemajuan PT Siloam Hospitals International Tbk pasca melakukan IPO, mengingat IPO berkontribusi meningkatkan modal usaha perusahaan tersebut. Sehubungan dengan hal 
tersebut, maka penulis menetapkan judul dalam penelitian ini yaitu "Analisis Rasio Profitabilitas pada PT Siloam Hospitals International Tbk". Tujuan dilakukannya penelitian ini adalah untuk menganalisis kinerja keuangan perusahaan pada PT Siloam Hospitals International Tbk tahun 2014 - 2017 ditinjau dari rasio profitabilitas.

\section{METODE PENELITIAN}

Rancangan penelitian pada penelitian ini adalah kuantitatif yaitu penelitian ilmiah yang sistematis terhadap bagian-bagian dan fenomena serta hubunganhubungannya. Tujuan penelitian kuantitatif adalah mengembangkan dan menggunakan model-model matematis, teori-teori dan/atau hipotesis.

Sampel dalam penelitian ini adalah PT Siloam Hospitals International Tbk dari tahun 2014 - 2017. Metode pengumpulan data yang digunakan dalam penelitian ini adalah metode studi dokumentasi. Dokumentasi adalah salah satu metode pengumpulan data kuatitatifyang diperoleh melalui Indonesia Capital Market Dictionary (ICMD) yang merupakan Informasi laporan keuangan perusahaan yang terdaftar pada Bursa Efek Indonesia, dengan mengkhususkan pada laporan keuangan pada PT Siloam Tbk.

Metode analisa data yang digunakan adalah deskriptif kuantitatif, yaitu analisis yang didasarkan pada perhitungan rasio untuk mengetahui tingkat profitabilitas yang digunakan sebagai dasar pengambilan keputusan. Data berupa laporan keuangan yang dianalisis dengan menggunakan rasio-rasio keuangan yang diperlukan untuk dapat memperoleh informasi mengenai profitabilitas yang terdiri dari Return On Asset Ratio (ROA), Return On EquityRatio (ROE), Net Profit Margin Ratio (NPM)) untuk menilai kinerja perusahaan.Rasio Profitabilitas. Rasio ini dihitung dengan cara:

$$
\begin{aligned}
& \text { Net } \text { Profit Margin }=\frac{\text { ProfitAfterTax }}{\text { Income }} \times 100 \% \\
& \text { Return on Equity }=\frac{\text { ProfitAfterTax }}{\text { Equity }} \times 100 \% \\
& \text { Return on Asset }=\frac{\text { ProfitAfterTax }}{\text { TotalAsset }} \times 100 \%
\end{aligned}
$$

\section{HASIL DAN PEMBAHASAN}

Lokasi penelitian yaitu PT Siloam Hospitals International Tbk dimana peneliti menggunakan data sekunder yang diperoleh dari publikasi Bursa Efek 
Indonesia maupun data keuangan yang terpublish di website yaitu PT Siloam Hospitals International Tbk, sehingga peneliti cukup dengan mencari data yang berhubungan dengan laporan profitabilitas PTSiloam Hospitals International Tbk. Selain itu, website idx memberikan keleluasaan bagi investor maupun peneliti untuk mengkaji kinerja keuangan perusahaan secara transparan.Pembahasan dari hasil perhitungan rasio profitabilitas yang terdiri dari Net Profit Margin, Return On Asset, dan Return On Equity pada PT Siloam Hospitals International Tbk pada tahun 2014 - 2017 adalah sebagai berikut :

\section{Tabel 1}

Kinerja Keuangan

\begin{tabular}{lcc}
\hline \multicolumn{1}{r}{ Keterangan } & $\mathbf{2 0 1 4}$ & $\mathbf{2 0 1 5}$ \\
\hline Laba Setelah Pajak & 51.309 .690 .808 & 67.605 .357 .023 \\
\hline Pendapatan & 2.415 .291 .830 .694 & 3.013 .142 .142 .653 \\
\hline Ekuitas & 1.653 .668 .551 .960 & 1.703 .892 .301 .906 \\
\hline Total Aset & 2.844 .085 .512 .104 & 3.013 .736 .264 .746 \\
\hline \multicolumn{1}{c}{ Keterangan } & $\mathbf{2 0 1 6}$ & $\mathbf{2 0 1 7}$ \\
\hline Laba Setelah Pajak & 94.831 .439 .696 & 70.062 .373 .918 \\
\hline Pendapatan & 3.824 .372 .630 .035 & 4.292 .086 .970 .181 \\
\hline Ekuitas & 3.129 .069 .996 .103 & 3.196 .668 .056 .829 \\
\hline Total Aset & 4.215 .689 .550 .079 & 4.520 .091 .422 .982 \\
\hline
\end{tabular}

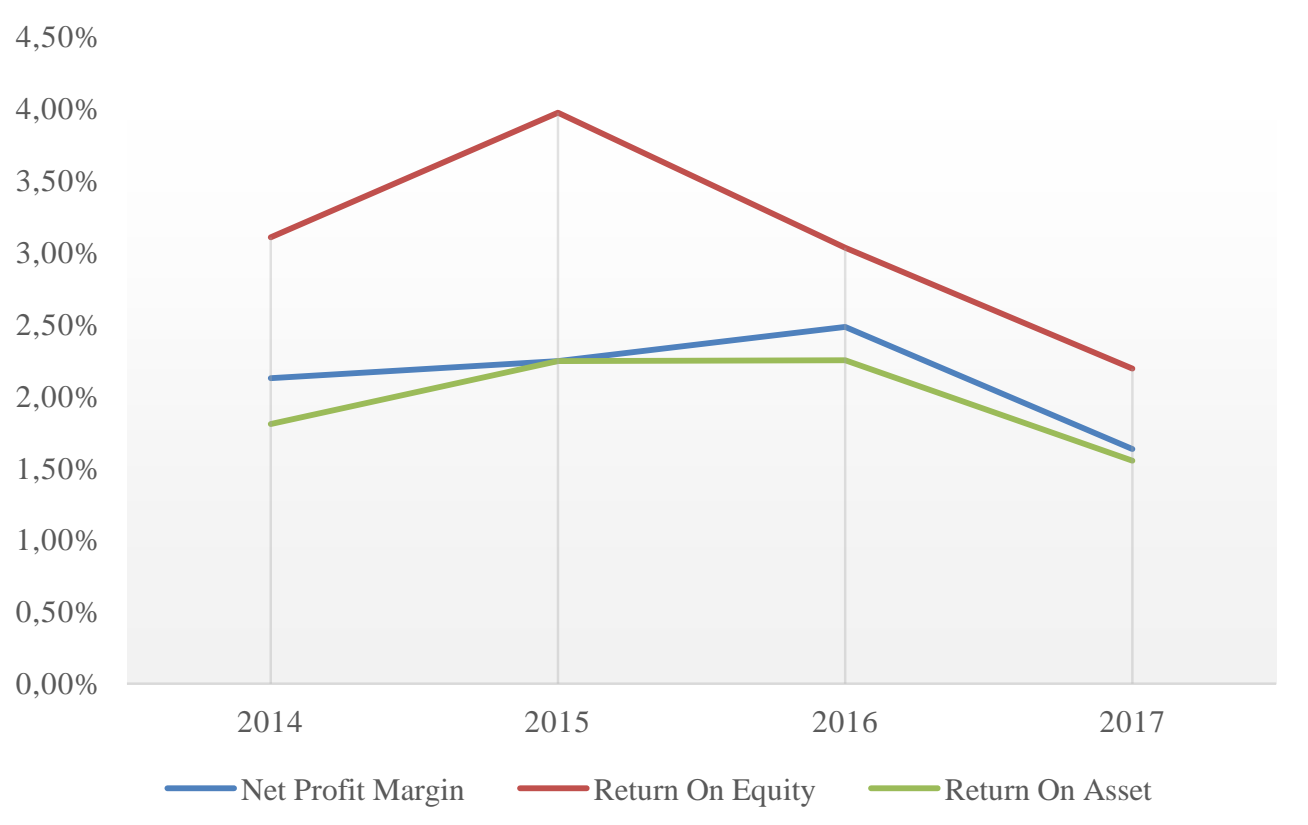

Gambar 1

Profitability Ratio in PT Siloam Hospital International Tbk 


\section{Net Profit Margin}

Net Profit Margin tinggi menunjukkan yaitu : 1)Semakin tinggi NPM menandakan laba perusahaan tersebut semakin tebal. 2)Semakin tinggi nilai NPM menandakan bahwa perusahaan tersebut semakin efisien operasionalnya. Perusahaan dapat menekan biaya-biaya yang tidak perlu, sehingga perusahaan mampu memaksimalkan laba bersih yang didapatkan. 3)Sebagai antisipasi melonjaknya bahan baku, biaya operasional seperti kenaikan gaji pegawai, ataupun melonjaknya beban keuangan seperti pembayaran bunga. Jika NPM perusahaan lebih tebal angkanya, maka ketika hal-hal diatas terjadi, laba bersih perusahaan tidak turun signifikan.

Tabel 2

Data Net Profit Margin

\begin{tabular}{lrrrr}
\hline $\begin{array}{l}\text { Net Profit } \\
\text { Margin }\end{array}$ & $\mathbf{2 0 1 4}$ & $\mathbf{2 0 1 5}$ & $\mathbf{2 0 1 6}$ & \multicolumn{2}{c}{$\mathbf{2 0 1 7}$} \\
\hline $\begin{array}{l}\text { Laba } \\
\text { Setelah }\end{array}$ & & & & \\
Pajak & 51.309 .690 .808 & 67.605 .357 .023 & 94.831 .439 .696 & 70.062 .373 .918 \\
\hline $\begin{array}{l}\text { Pendapata } \\
\text { n }\end{array}$ & 2.415 .291 .830$. & 3.013 .142 .142$. & 3.824 .372 .630$. & 4.292 .086 .970$. \\
& 694 & 653 & 035 & 181 \\
\hline \multicolumn{1}{c}{ Rasio } & & & & \\
\multicolumn{1}{c}{ NPM } & $\mathbf{2 , 1 2 \%}$ & $\mathbf{2 , 2 4 \%}$ & $\mathbf{2 , 4 8 \%}$ & $\mathbf{1 , 6 3 \%}$ \\
\hline
\end{tabular}

Pembahasan Net Profit Margin (NPM) PTSiloam International Hospital Tbk telah meningkat pada tahun 2014 - 2016 sebesar 0,36\% tetapi menurun pada tahun 2017 sebesar 0,85\% sehingga dapat disimpulkan pada tahun 2017 kemampuan perusahaan dalam menghasilkan laba bersih yang berasal dari penjualan atau pendapatan menurun.Berdasarkan tingkat kesehatan keuangan perusahaan, perusahaan dengan tingkat NPM di atas 5\% (NPM > 5\%) dikatakan sehat yang berarti PT Siloam Hospitals International Tbk(SILO) pada tahun 2014 - 2017 memiliki nilai NPM-nya di bawah 5\% selama 4 tahun berturut-turut sehingga tingkat kesehatan NPM PT Siloam International Hospital Tbk tidak sehat dan rendah. 


\section{Return On Equity}

Return On Equity tinggi menunjukkan yaitu : 1) Semakin tinggi ROE menunjukkan semakin efisien perusahaan dalam menggunakan modal sendiri untuk menghasilkan laba investor yang ditanam pada perusahaan. 2)Naiknya rasio ROE dari tahun ke tahun pada perusahaan berarti terjadi adanya kenaikan laba bersih dari perusahaan yang bersangkutan. Naiknya laba bersih dapat dijadikan salah satu indikasi bahwa nilai perusahaan juga naik karena naiknya laba bersih sebuah perusahaan yang bersangkutan akan menyebabkan harga saham yang berarti juga kenaikan dalam nilai perusahaan

Tabel 3

Data Return On Equity

\begin{tabular}{|c|c|c|c|c|}
\hline $\begin{array}{l}\text { Return } \\
\text { On Equity }\end{array}$ & 2014 & 2015 & 2016 & 2017 \\
\hline \multicolumn{5}{|l|}{ Laba } \\
\hline \multicolumn{5}{|l|}{ Setelah } \\
\hline \multirow[t]{2}{*}{ Pajak } & 51.309 .690 .808 & 67.605 .357 .023 & 94.831 .439 .696 & 70.062.373.918 \\
\hline & 1.653 .668 .551$. & 1.703 .892 .301 & 3.129 .069 .996$. & 3.196 .668 .056 .8 \\
\hline Ekuitas & 960 & 906 & 103 & 29 \\
\hline \multicolumn{5}{|l|}{ Rasio } \\
\hline ROE & $3,10 \%$ & $3,97 \%$ & $3,03 \%$ & $2,19 \%$ \\
\hline
\end{tabular}

Pembahasan Return on Equity (ROE) PTSiloam Hospitals International Tbk menunjukkan peningkatan pada tahun 2014-2015 sebesar 0,87\%; tetapi menurun pada tahun 2015-2017 sebesar 1,78\%; sehingga dapat disimpulkan pada tahun 2017 kemampuan perusahaan dalam menghasilkan laba bersih yang berasal dari ekuitas menurun. Jika didasarkan pada kesehatan kinerja keuangan Return On Equity, perusahaan adalah dikatakan sehat jika lebih dari 12\%. PTSiloam Hospitals International Tbk(SILO) ROE-nya selama 4 tahun berada di bawah $12 \%$ sehingga dapat dikatakan perusahaan ini tidak sehat.

\section{Return On Asset}

Return On Asset (ROA) tinggi menunjukkan yaitu :perusahaan tersebut berpeluang besar dalam meningkatkan pertumbuhan tetapi jika total aktiva yang digunakan perusahaan tidak memberikan laba, maka perusahaan akan mengalami kerugian dan akan menghambat pertumbuhan perusahaan tersebut.Return on Asset (ROA) menggambarkan sejauh mana tingkat pengembalian dari seluruh asset yang dimiliki perusahaan. 


\section{Tabel 4}

Data Returm On Asset

\begin{tabular}{lrrrr}
\hline $\begin{array}{l}\text { Return On } \\
\text { Asset }\end{array}$ & $\mathbf{2 0 1 4}$ & $\mathbf{2 0 1 5}$ & $\mathbf{2 0 1 6}$ & \multicolumn{2}{c}{$\mathbf{2 0 1 7}$} \\
\hline $\begin{array}{l}\text { Laba } \\
\text { Setelah }\end{array}$ & & & & \\
Pajak & 51.309 .690 .808 & 67.605 .357 .023 & 94.831 .439 .696 & 70.062 .373 .918 \\
\hline & 2.844 .085 .512$. & 3.013 .736 .264$. & 4.215 .689 .550$. & 4.520 .091 .422$. \\
Total Asset & 104 & 746 & 079 & 982 \\
\hline Rasio ROA & $\mathbf{1 , 8 0 \%}$ & $\mathbf{2 , 2 4 \%}$ & $\mathbf{2 , 2 5 \%}$ & $\mathbf{1 , 5 5 \%}$ \\
\hline
\end{tabular}

Pembahasan Return on Assets (ROA) PTSiloam Hospitals International Tbkmenunjukkan peningkatan pada tahun 2014-2016 sebesar 0,45\% dan penurunan pada tahun 201-2017 sebesar 0,7\%; sehingga dapat disimpulkan pada tahun 2017 kemampuan perusahaan untuk menghasilkan laba bersih yang berasal dari total aset juga menurun. Jika didasarkan pada kesehatan kinerja keuangan Return On Assets, perusahaan dikatakan sehat jika nilai ROA di atas 2\% (ROA > 2\%). PT Siloam Hospitals International Tbk(SILO) ROA selama 4 tahun di bawah $2 \%$ sehingga dapat dikatakan perusahaan ini tidak sehat.

\section{PENUTUP}

Simpulan dari penelitian ini adalah :

1. Peningkatan nilai NPM menunjukkan kinerja perusahaan lebih produktif, sehingga akan meningkatkan kepercayaan investor untuk berinvestasi di perusahaan. Rasio ini menunjukkan berapa persen dari pendapatan bersih yang diperoleh dari setiap penjualan atau pendapatan. Semakin besar rasio ini, semakin baik kemampuan perusahaan untuk menghasilkan laba yang tinggi. Pada tahun 2014-2017rasio NPM PTSiloam Hospitals International Tbk menurun, menunjukkan bahwa kinerja keuangan yang rendah didasarkan pada pendapatan.

2. Tingkat ROE yang tinggi menunjukkan bahwa perusahaan dapat memperoleh tingkat laba yang tinggi dibandingkan dengan tingkat ekuitasnya, dengan kata lain kemampuan manajemen untuk menggunakan modal sahamnya untuk operasinya menghasilkan keuntungan tambahan bagi perusahaan. ROE PTSiloam Hospitals International Tbk menurun. Hal ini menunjukkan bahwa kurangnya kinerja keuangan yang efektif didasarkan pada ekuitasnya.

3. Peningkatan nilai ROA menunjukkan perusahaan memiliki peluang besar untuk meningkatkan pertumbuhan, tetapi jika total aset yang digunakan oleh perusahaan tidak memberikan keuntungan maka perusahaan akan mengalami kerugian dan akan menghambat pertumbuhan. Dalam rasio ROA PTSiloam 
Hospitals International Tbk pada tahun 2014-2017 mengalami penurunan. Hal ini menunjukkan bahwa kinerja keuangan yang kurang optimal didasarkan pada total asetnya.

\section{Saran}

Saran penulis bagi penelitian di masa mendatang agar diperoleh penyempurnaan, diantaranya yaitu :

1. Para peneliti yang tertarik untuk melakukan penelitian di bidang yang sama dapat menggunakan proksi lain yang lebih beragam mengingat banyaknya variabel untuk mengukur kinerja keuangan perusahaan.

2. Penelitian selanjutnya diharapkan mengkomparasi dengan beberapa perusahaan industri kesehatan di Bursa Efek Indonesia, sehingga dapat memberikan gambaran perusahaan kesehatan yang memiliki kinerja keuangan yang baik.

\section{DAFTAR PUSTAKA}

Algifari (2010). Analisis Regresi : Teori, Kasus dan Solusi. Yogyakarta : Yogyakarta.

Ang, Robert. (2010). Buku Pintar Pasar Modal Indonesia, Mediasoft.com

Anggita, Teti. (2016). Faktor - faktor yang mempengaruhi Asimetri Informasi pada Bursa Efek Indonesia.

Brigham, Eugene. (2015). Manajemen Keuangan. Jakarta : Erlangga.

Data Sekunder Laporan Keuangan Perusahaan yang menjadi Sampel Penelitian dan Perkembangan Bursa Saham Indonesia. Agustus 2017. www.idx.co.id

Gujarati, Damodar. (2010) Basic Econometrics, America : Mc Graw-Hill International Edition.

Husnan, Suad. (2010). Dasar - Dasar Teori Portofolio dan Analisis Sekuritas, Yogyakarta: UPP STIM YKPN.

Jogiyanto. (2010). Teori Portofolio dan Analisis Investasi. Yogyakarta : BPFE.

Nusale, Grimaldy. (2017). Analisis Rasio Profitabilitas pada PT. SUMBER ALFARIA TRIJAYA, TBK (ALFAMART). Jurnal Administrasi Bisnis Vol 5, No 002 (2017).ejournal.unsrat.ac.id

Perkembangan Pasar Modal Indonesia. Maret 11, 2017. www.bi.go.id

IDX IPO Stock Performance. . Maret 11, 2017. www.e-bursa.com :

Sawir, Agnes. (2009). Analisa Kinerja Keuangan dan Perencanaan keauangan Perusahaan. Jakarta : PT. Gramedia Pustaka Utama.

Sulastri, Putu \& Nurul Marta Hapsari. (2014). Analisa Rasio Keuangan untuk menilai Kinerja Keuangan Perusahaan (Studi Kasus pada PT. Andalan Finance Indonesia Tahun 2011-2013) 
Syafri Harahap, Sofyan (2008). Analisa Kritis atas Laporan Keuangan. Jakarta : PT. Raja Grafindo Persada.

Renny Suprapti Ningsih. (2015). Analisis Rasio Profitabilitas Terhadap Laporan Keuangan PT. Bank Tabungan Negara (Persero) Tbk. Journal Ilmu Administrasi Bisnis, 2015, 3 (2): 519-530. ejournal.adbisnis.fisipunmul.ac.id

Tandelilin, Eduardus. (2010). Portofolio dan Investasi, Teori dan Aplikasi, Ed.pertama. Yogyakarta : Kanisius.

Sulastri, Putu. 2014. Analisa Rasio Keuangan untuk Menilai Kinerja Keuangan Perusahaan (Studi Kasus pada PT. Andalan Finance Indonesia Tahun 2011-2013). Jurnal Ekonomi Manajemen Akuntansi 2015.ejournal.stiedharmaputrasmg.ac.id/index.php/JEMA/article/viewFile/ $214 / 185$ 